УДК 792.01

DOI https://doi.org/10.24919/2308-4863/40-2-6

\title{
Надія КУКУРУЗА,
} orcid.org/0000-0002-3930-9422 кандидат мистеитвознавства, доиент, завідувач кафедри сиенічного мистецтва і хореографії

Навчально-наукового інституту мистеитв Прикарпатського національного університету імені Василя Стефаника (Івано-Франківськ, Украӥна) kukuruza.nv@gmail.com

\section{КОНЦЕПЦІЯ БОГДАНА БОЙЧУКА У ВИРІШЕННІ ВЗАСМОДІЇ ЛІТЕРАТУРНОГО І ТЕАТРАЛЬНОГО ПРОСТОРУ В СЕРЕДОВИЩІ УКРАЇНСЬКОЇ ДІАСПОРИ}

У статті здійснено спробу виокремити один з аспектів творчої діяльності учасника неформального об'єднання українських поетів та прозаїків (1950-1990 роки) у Нью-Йорку - поета, прозаїка, перекладача та літературного критика Богдана Бойчука, зосередивши увагу на сценічному втіленні постановок за його творами в середовищі діаспори. Б. Бойчук, як активний дослідник $і$ знавець сучасних світових театральних процесів, вивчав і аналізував творчість відомих театральних діячів ХХ століття: С. Гротовського, П. Брука, С. Беккета, Р. Вілсона й інших. Він також був поиіновувачем творчості Леся Курбаса, відстежував театральне життя на теренах України, постановки режисерки з українським корінням В. Ткач у театрі «Ля Мама» у Нью-Йорку, режисерську працю В. Кучинського у Львівському театрі імені Леся Курбаса.

Б. Бойчук зазначав новаторство й унікальність сиенічного втілення n'єси «Голод (1933)» режсисером В. Лисняком, але все ж розумів, шзо театр украӥнської діаспори, навіть здійснивши таку спробу, не може подолати тяглості до реалістичної гри, диктованої традиціями постановок украӥнського класичного репертуару, а значить, не міг бути готовий до експериментів із модерною драматургією.

Варто відзначити вагомий внесок письменника Б. Бойчука в його намаганні змінити вектор розвитку українського театру діаспори, зробити його відкритим для експериментальної творчості, яка давно практикувалася у світовому театрі.

Письменник також уважно стежив за виставами дитячого театру СМС і висловлював думку про те, щуоб в його репертуарі повинні бути найкращчі взіриі світової драматургї в украйнському перекладі. Поезія Б. Бойчука також була втілена у Студії Мистещького Слова під орудою Лідії Крушельницької у драматичній філософській композииії «П'ять картин 2000-го року».

3 1990-х років постановки текстів Б. Бойчука в Украӥні здійснили режисери - експериментатори за духом Сергій Проскурня і Сергій Архипчук у театрі «Мушля».

Ключові слова: тяглість традииій, «Голод (1933)», драматургія, модернізм, театральний простір, експериментальний театр, стилізування.

\section{THE CONCEPT OF BOHDAN BOICHUK IN RESOLVING THE INTERACTION OF LITERARY AND THEATER PROCESSES IN THE UKRAINIAN DIASPORA}

The article attempts to single out one of the aspects of the creative activity of poet, prose writer, translator and literary critic Bohdan Boichuk, the participant of the informal association of Ukrainian poets and prose writers (1950-1990) in New York, focusing on the stage embodiment of productions of his works among the diaspora. B. Boichuk, as an active researcher and expert in modern world theatrical processes, studied and analyzed the works of famous theatrical figures of the twentieth century Ye. Grotovskoho, P. Bruka, S. Bekketa, R. Vilsona and others.

He was also a connoisseur of Les Kurbas's work, tracked theatrical life in Ukraine, productions of the director with Ukrainian roots V. Tkach at the La Mama Theater in New York, V. Kuchynskyi's directorial work at the Lviv Les Kurbas Theater. 
Claiming the innovation and uniqueness of the stage embodiment of the play "The Famine (1933)" directed by $V$. Lysniak, B. Boichuk still understood that despite making an attempt, the theater of the Ukrainian diaspora, was not able to overcome the longevity of traditions of realistic play, dictated by productions of Ukrainian classical repertoire, and therefore could not be open to experiments with modern dramaturgy.

It should be noted the significant contribution of the writer B. Boychuk and his attempts to change the vector of development of the Ukrainian theater in the diaspora, to make it open to experimental work, which has long been practiced in world theater.

The writer also closely followed the performances of the children's SMS theater and expressed the opinion that his repertoire should include the best examples of world drama in Ukrainian translation. B. Boichuk's poetry was also embodied in the Studio of the Artistic Word under the direction of Lidiia Krushelnytska in the dramatic philosophical composition "Five Paintings of the Year 2000".

Since 1990's, B. Boichuk's texts were staged in Ukraine by experimenters and directors S. Proskurnia and S. Arkhypchuk in the theater "Mushlia".

Key words: longevity of traditions, "The Famine (1933)", dramaturgy, modernism, theatrical space, experimental theater, stylization.

Постановка проблеми. Актуальність проблематики статті зумовлена дослідженням драматургічної творчості Б. Бойчука головно з позицій літературознавства. Як активний прискорювач і натхненник взаємодії літературних і театральних процесів у середовищі української діаспори Б. Бойчук стає першопрохідцем у сценічній реалізації постановок власних модернових творів як на театральній сцені, так і на літературній естраді.

Аналіз досліджень. До значних наукових досліджень мистецтва української діаспори віднесімо наукові праці вітчизняних учених В. Дутчак (Дутчак, 2013) і Г. Карась (Карась, 2012), де системно проаналізовано творчість композиторів і музикантів діаспори, зокрема, на перетині творчої співпраці з літераторами, театральними діячами. Опрацьований науковцем В. Гайдабурою численний епістолярій, зібраний особисто ним фактичний матеріал, його грунтовні наукові висновки дали змогу детальніше познайомитися із творчістю театральних діячів діаспори (Гайдабура, 2006). Історія становлення і розвитку сценічного мистецтва діаспори опрацьована авторкою статті, а також проаналізована в дисертаційній роботі й окремих наукових дослідженнях (Кукуруза, 2016; Кукуруза, 2020а; Кукуруза, 2019а; Кукуруза, 2019b; Кукуруза, 2020b; Кукуруза, 2020с).

Серед останніх праць, присвячених взаємодії літературного і театрального процесів, зокрема в середовищі української діаспори, - книжка статей «Навіщо про це говорю. Театр. Балет. Література», що допомагає відстежувати культурномистецькі, літературні процеси в Україні та світі очима Богдана Бойчука (передмова літературознавця В. Габора (Бойчук, 2017)).

Варто відзначити останні наукові праці літературознавців, у яких розглянуто аспект драматургічної творчості письменника Б. Бойчука.

Зокрема, літературознавець Г. Косарєва зробила спробу окреслити цілісну концепцію підсумкової збірки статей Богдана Бойчука як своєрідну антологізацію метамистецтва діаспорної атмосфери як «спільноти пам'яті» емігрантів та його сучасників: митців-маргіналів (Косарєва, 2019: 55).

Літературознавець і перекладач Т. Карабович у науковій праці «Досвід надії та самотності в літературному дискурсі Богдана Бойчука» стверджує про намагання письменника разом із колегами 3 Нью-Йоркської групи (драматургія Віри Вовк, Ю. Тарнавського) змінювати «обличчя українського театру в еміграційному середовищі XX ст.», який часто порівнював 3 американською сценою (Карабович, 2015: 127).

Науковець М. Коновалова аналізує п'єсу «Голод (1933)» і висловлює думку, що «екзистеційна проблема свободи людини як найвищої цінності позиціонується на тлі національної трагедії і виражається через конфлікт людини і системи. Тема абсурдності людського буття посилюється зовнішнім чинником - голодом» (Коновалова, 2015: 135). Також вона аналізує твір із позицій модернізму, визначає жанрові особливості твору, аспекти проблематики, роль діалогу як домінантного фабульного компонента драматичного тексту (Коновалова, 2015: 135).

Мета статті - визначити вагомість внеску драматургії письменника Б. Бойчука в його намаганні змінити вектор розвитку українського театру діаспори, наповнити репертуар театрів творами новітньої драматургії, зробити його відкритим для експериментальної творчості.

Виклад основного матеріалу. Поштовхом до написання Б. Бойчуком п'єс постала ситуація й умови, у яких опинився український театр у діаспорі. Погоджуємося 3 думкою літературознавця T. Карабовича, що «загалом український театр у вигнанні був затаврований історичною потребою простору, тому вимагав від акторів у новому середовищі гнучкості та намагання здобувати нового глядача, що не було легкою справою. Емі- 
Кукуруза Н. Концепція Богдана Бойчука у вирішенні взаємодії мітературного і театрального простору...

граційна сцена живилася сценічним репертуаром драматичних творів Івана Котляревського, Тараса Шевченка та Лесі Українки. Богдан Бойчук вважав це за анахронізм. Тому мистецтво театру для Нью-Йоркської групи розумів за новим викликом свідомості. < ..> Богдан Бойчук стає автором таких драматичних творів, як «Голод» (написано у 1961-1962 рр.), «Приречені» (1963р.), «Регіт» (1972 р.) та інші. На жаль, ці п’єси, незважаючи на високий рівень американської сцени, не вдалося реалізувати в театрі» (Карабович, 2015: 126).

Тож перша постановка драми «Голод (1933)» відбулася в Нью-Йорку 19 квітня 1969 р. за постановки Володимира Лисняка, режисера, актора, художника театру, що навчався професії в Театрі-студії Й. Гірняка і О. Добровольської, продовжувачів справи реформатора українського театру Леся Курбаса, а отже, можемо твердити про певну тяглість театральних традицій, що не випадково привело до співпраці Б. Бойчука з режисером В. Лисняком, адже він розумів виклики, що постають перед постановником такого матеріалу. На нашу думку, постановка вистави в розумінні Б. Бойчука вимагала стилю й ексериментаторства вистав «Березоля», що «базувався на двох компонентах: на слові та перетвореному жесті $<\ldots>$ Перетворений жест - це робоча метафора Курбаса, це вкладання змісту в жест. Тоді слово і жест стають одноправні, і режисер їх вживає рівномірно, відповідно до задуму $<\ldots>$ Для кожної вистави був інший зміст і $<\ldots>$ інакше перетворений жест» (Бойчук, 2017: 95).

Поштовхом до написання драми був 1933 р., але проблему «голоду і голодної смерті письменник висвітлив у загальнолюдському аспекті», застосувавши християнську символіку для підкреслення людяності» (Соловій, 1978b: 81).

Для дальшого аналізу самої постановки не можемо оминути структуру і зміст п'єси, драматичної поеми: пролог як «драматично-балетне дійство», у якому чути «Голос від Розп'яття», і дев'ять сцен, у яких головними персонажами $\epsilon$ «Жінка 3 дитиною», яка вірить, що «треба помогти людині», i «Мужчина», якого роздирають внутрішні суперечності, але своєю волею він таки рятує власною кров'ю чужу дитину, а отже, «людина навіть у найбільш невигідних ситуаціях своїми безкорисними ділами доказує свою вільну волю і потребує другої людини» (Залеська-Онишкевич, 1969).

Думку щодо появи двох п’єс Б. Бойчука і постановки «Голоду (1933)» напередодні висловила Л. Залеська-Онишкевич, яка проаналізувала текстову основу твору. На іï думку, Б. Бойчук пору- шує дві теми: «вбивання людей, замість спільно «дерти темряву», і вартість індивідуальної свободи для себе у вирішуванні власних поступків». Авторка наголошує на сильному напруженні в атмосфері твору, високій поетизації мови і цікавості, як саме «ці поетичні картинки будуть передані на сцені $<\ldots>$, яку інтерпретацію твору надасть у прем'єрі режисер Володимир Лисняк» (Залеська-Онишкевич, 1969).

Про прем'єру вистави відгукнувся дописувач часопису «Свобода» Т. Конюшко, у якому аналізує саму постановку, гру акторів і окреслює перспективи експериментального театру в діаспорі: «Режисер і головний актор драми В. Лисняк вибрав метод найбільш прямого відтворення, можливість, яку слід уважати радше відхиленням від складніших проблем творчої режисерії. У цій поставі не було несподіванок, так би мовити несподіванок сценічних ефектів, сценічних ідей, не передбачених текстом - читачем, і тому ми схильні окреслити його поставу традиційною $<\ldots>$ Гра Лисняка i його дружини, Лариси Кукрицької, Володимира Королика, Ольги Кириченко і взагалі цілого ансамблю була на доброму рівні <...> Зі справою утримання театру, а зокрема експериментального театру, у нас невесело. Та цей факт не міняє особливої потреби саме такого експериментального театру <..> Може б відповідь шукати в одноактівках з кількома варіантами виконання, що може бути справою одного або більшого числа режисерів». Автор також критично висловився про загальнолюдський контекст вистави, уважаючи, що для глядача діаспори «трагедія українського народу проминула майже неусвідомленим духово (духовно - H. К.) фактом» (Конюшко, 1969). Це підтверджує бажання пересічного діаспорного глядача дивитися в театрі традиційний класичний репертуар або ж на тематику, де ностальгійно співпереживати 3 акторами на сцені найтрагічніші моменти героїчної національно-визвольної боротьби українського народу.

Так само постановку детально проаналізував маляр і письменник-есеїст Юрій Соловій, який намагався визначити співмірність тексту і сценічного втілення, висловив критичну думку щодо режисури В. Лисняка (костюми, сценографія, світло, звук), а також окреслив перспективи діяльності «Нового театру»:

- «Голод» (1933)» - безсумнівний сценічний матеріал, що вимагає експресіоністично-абстрактного театрального підходу як виразник протилежного до реалізму й натуралізму. Експресіонізм як максимально психічний вираз, абстрактність як фізично-зоровий; 
- позачасову монотонність мали б відтворювати костюми, що віддзеркалюють понадчасовість. Натомість вони $є$ стилізуванням під лаконічно народне, під етнографізм: спідниці, ногавиці, хустки, пазухи, які контрастують із драмою, у якій далеко не йдеться про історичну автентичність чи автентичність певної місцевості;

- традиційними для постановок стають неприкриті куби як претензія на новаторство. Ця голизна часто використовується для притягання глядачів і вони стають тільки трюком модерної сцени, доповнюючи реквізит стерилізованого культурного життя;

- щодо освітлення, яке Б. Бойчук уважає «рембрантівським», то його не можемо віднести до новацій у театральних постановках;

- щодо теми режисера в сучасному театрі, то сьогодні від нього очікують своєрідного театрального дійства на принципі творення, а не на принципі копіювання. До послуг режисера - акторська кваліфікація, а не актор як «душа» театру. У цьому контексті один із виконавців ролі загалом порушив режисерську концепцію вистави, переростаючи самого режисера;

- хоча Б. Бойчук і сконцентровує увагу на позасценічних елементах, які, на його думку, роблять виставу унікальною, і вважав такі зауваги щодо костюмів і декорації неістотними, «зовнішніми», - саме така їхня наявність позбавляе відчуття глибини задуму;

- гра акторів у традиціях реалістичного театру, лаконічно-етнографічні костюми, сцена 3 кубів, що не відповідають стилістиці гри і костюмів; фрагментарність доброї голосової передачі і жесту, вдалого виходу актора, давно віднайдений засіб світлового оформлення не мають жодного стосунку до ідеї і стилю драми, а отже, режисура В. Лисняка - це не початок нової театральної реформи в театрі української діаспори (Соловій, 1978a: 262-266).

Б. Бойчук обстоює своє найперше сценічне дітище, уважає виставу-експеримент вдалою: «Кожен режисер творить свій стиль, свої методи постановки $<\ldots>$ Порожня етикета - безвартісна $<\ldots>$ Добре зроблена робота повинна бути відомим фактом. А робота була зроблена добре» (Соловій, 1978b: 84). «Суть не в тому, яку фарбу вживає маляр, суть у тому, як він малює; те саме стосується й режисера, бо нема традиційних лаштунків, $є$ традиційні драми, які можна ставити традиційно і модерно, $є$ т. зв. «модерні» драми, які можна ставити традиційно і модерно. Хочу сказати, що драматургія і театр - це два окремі світи, які не обов' язково мусять себе взаємно зв'язувати чи обмежувати» (Соловій, 1978b: 87).
Полеміка літератора і митця стосовно втілення «Голоду (1933)» не тільки виявила їхні погляди на постановку, але й спонукала до роздумів про експериментуванням із сучасною драматургією в театрі української діаспори, яке так і залишилося відкритим і змогло виявити себе у творчості режисерки з українським корінням Вірляни Ткач через кілька десятиріч.

У контексті наступної відомої постановки за поезіями Б. Бойчука варто сказати про нього як про активного дослідника історії українського театру на теренах діаспори. Він став упорядником творчої спадщини акторів-березільців Гірняка i Добровольської, активно підтримував творчі стосунки зі Студією Мистецького Слова Л. Крушельницької, брав активну участь в обговоренні вистав.

Так само, як і до репертуару дорослих театрів, уважно ставився Б. Бойчук до підбору репертуару дитячого театру.

Після перегляду вистави «Голуба хустина» українського радянського письменника А. Шияна він, вочевидь, складає свою думку про якість драматургічного матеріалу i, вітаючи постановників та учасників загалом, робить висновок: «Щоб студія могла рости, треба цікавих і добрих п'єс. А їх немає $<\ldots$..> Добрі діточі п'єси не народяться тільки тому, що вони потрібні. Якщо вони не народилися досі, із внутрішньої потреби письменників, то не народяться у близькому майбутньому. Але можна вибрати декілька чужомовних п'єс і перекласти» (Бойчук, 1968). Отже, письменник пропонує перекладати українською кращі взірці світової дитячої літератури, уважає, що тільки на таких може розвиватися колектив. На це його побажання гостро відреагував письменник Леонід Полтава, який ставить питання про можливість виховання дітей діаспори тільки на українському матеріалі (Полтава, 1968).

Отже, постановкою драматичної композиції філософських «П'яти картин 2000-го р.» Б. Бойчука (Гайдабура, 2006: 129) Студія Мистецького Слова заявляє, що їй під силу сценічне втілення сучасної модерної поезії.

Театрознавець В. Гайдабура підкреслює іiі «філософську й естетичну вартісність» і розглядає появу у сценічному репертуарі творів Б. Бойчука як «неординарність факту»; сам сюжетний код твору - ніби «духовний рентген», де осмислюють людське життя від народження до смерті $<\ldots>$ Фінал вистави - колективне звернення до Бога, прохання про просвітлення і спокою перед відходом у вічність (Гайдабура, 2006: 146-147). У виставі, крім двадцяти студійців, брав участь відомий актор діаспори Іван Бернацький, для музичного оформлення використали музику Мирослава Скорика. 
Не оминемо і той факт, що студійці Л. Крушельницької також виконували поезії Віри Вовк як окремо, так і в літературних композиціях (Гайдабура, 2006: 45, 130).

Переїхавши до Києва, Б. Бойчук укріпив зв'язки між письменниками діаспори й України, здійснив критичну переоцінку власної драматургічної творчості: від чогось відмовився, деякі твори готував до друку.

Як ще одне зі сценічних утілень на основі драм «Голод (1933)» і «Приречені любити» композитор Віктор Балей створив оперу «Червона земля. Голод», яка стала найвідомішою постановкою за творами автора (Архів Н. Кукурузи).

Висновки. Отже, постать Богдана Бойчука у вирішенні концепції літературного і театрального простору в середовищі української діаспори можемо оцінювати так:

Богдан Бойчук найперший iз письменників Нью-Йоркської групи починає співпрацюз театром української діаспори 3 метою відкриття простору для експериментування з модерною драматургією, як це відбувається у практиках світового театру;

- сприймаючи аргументацію щодо постановки вистави «Голод (1933)» як «невдалий експеримент», Б. Бойчук усе ж розглядає постать режисера як особистість, що має сповідувати свій стиль і свої методи роботи;

- зважаючи на великий розрив у тридцять років між першою й останньою постановками автора в «Новому театрі» і СМС у середовищі діаспори, можемо зробити висновок, що, на жаль, автор не намагався більше здійснювати спроб сценічного втілення власних творів, але й далі вітав появу нових драматичних творів українських письменників діаспори.

- Ще одна із причин такого розриву - відхід старшого покоління театральних митців і відсутність належної зміни (через соціально-побутові обставини), яка б підтримувала і розвивала театр діаспори на професійних засадах, а не засадах аматорства;

- виховним аспектом творчої діяльності дитячих студій Б. Бойчук убачав утілення найкращих зразків світової драматургії, закликав письменників робити їхні переклади, таким чином підтримувати зв'язок із театром діаспори загалом.

Перспективи майбутніх наукових розвідок убачаємо в дослідженні сценічних адаптацій творів Б. Бойчука в Україні, до яких причетні знані театральні режисери С. Проскурня, В. Вовкун, С. Архипчук.

\section{СПИСОК ВИКОРИСТАНИХ ДЖЕРЕЛ}

1. Бойчук Б. Навіщо про це говорю. Львів : Піраміда, 2017. 430 с.

2. Бойчук Б. Напередодні «Голубої хустини». Свобода. 21 березня 1968. Ч. 54. С. 4.

3. Гайдабура В. Летючий корабель Лідії Крушельницької. Студія Мистецького Слова в Нью-Йорку. Київ : Факт, 2006. $280 \mathrm{c}$.

4. Дутчак В. Бандурне мистецтво українського зарубіжжя XX - початку XXI ст. : монографія ; Прикарпат. нац. ун-т ім. Василя Стефаника, Івано-Франків. обл. орг. Нац. спілки кобзарів України. Івано-Франківськ : Фоліант, 2013. 488 с.

5. Залеська-Онишкевич Л. Перед прем’єрою «Голоду». Свобода. 16 квітня 1969. Ч. 69. С. 3.

6. Карабович Т. Досвід надії та самотності в літературному дискурсі Богдана Бойчука. Літературний проиес: методологія, імена, тендениії. Філологічні науки. 2015. № 6. C. 122-127. URL: http://nbuv.gov.ua/UJRN/Litpro_2015_6_27.

7. Карась Г. Музична культура української діаспори у світовому часопросторі XX ст. Івано-Франківськ : Тіповіт, 2012. $1164 \mathrm{c}$.

8. Коновалова М. Модерні експерименти у структурі п’єси Б. Бойчука «Голод (1933)». Вісник Донеиького наиіонального університету. 2015. Серія Б «Гуманітарні науки». № № 1-2. C. 135-139. URL: http://nbuv.gov.ua/UJRN/ vdnug $2015 \quad 1-2 \quad 25$.

9. Конюшко $\bar{\Gamma}$. Трагедія народу - драма людства. Про Бойчукову драму «Голод» і її поставу. Свобода. 30 квітня 1969. Ч. 79. С. 2.

10. Косарєва Г. Метамистецтво Богдана Бойчука: театрально-літературні рефлексії у збірці статей «Навіщо я про це говорю». Наукові праці Чорноморського національного університету імені Петра Могили : науковий журнал / ред. кол.: О. Пронкевич (гол.) та ін. Миколаїв, 2019. Т. 325. Вип. 313. С. 55-60.

11. Кукуруза Н. Архів Н. Кукурузи: інтерв’ю, аудіозаписи, листування (текст; аудіо).

12. Кукуруза Н. Втілення літературної композиції в українському сценічному мистецтві: жанрова й формотворча специфіка, історична динаміка : автореф. дис. ... канд. мистецтвозн.: 17.00.02. Київ, 2016. 20 с.

13. Кукуруза Н. Жанр ревю в мистецтві української діаспори: витоки, канон, імена, тематика. Українська культура : минуле, сучасне, шляхи розвитку : науковий збірник. Рівне : РДГУ, 2020. Вип. 34. С. 186-192.

14. Кукуруза Н. Творчість Лесі Українки в театральному мистецтві діаспори. Леся Українка в діаспорному літературознавстві. Німецько-украӥнські зв'язки : збірник наукових праць за матеріалами Міжнародної наукової конференції в Мюнхені, 3-7 квітня 2019 р. / укл. і заг. ред. : Д. Блохин, М. Моклиця, Т. Осадца. Мюнхен ; Тернопіль, 2019. C. $138-147$.

15. Кукуруза Н. Франкіана у мистецтві художнього слова української діаспори другої пол. XX-XXI ст. Українська культура: минуле, сучасне, иляхи розвитку : науковий збірник. Рівне : РДГУ, 2019. Вип. 32. С. 19-25.

16. Кукуруза Н. Жанрово-формова специфіка втілення художнього слова в сценічному мистецтві української діаспори другої половини ХХ ст. Діалог мов - Діалог культур. Украӥна із глобальної перспективи : матеріали Х Міжнародної віртуальної конференції українознавства. Дортмун д: Readbox GmbH, 2020. С. 590-597. 
17. Кукуруза Н. Професійне виконавське мистецтво як вираз національної духовної та культурної спадщини української діаспори. Мистещькі духовні виміри украӥнської діаспори : колективна наукова монографія / В. Дутчак та ін. Даллас, США : Primedia eLaunch LLC, 2020. С. 107-145.

18. Полтава Л. За український репертуар для дитячих театрів. Свобода. 2 квітня 1968. Ч. 62. С. 3

19. Соловій Ю. За новий театр, але не за «Новий театр» / Про речі більші, ніж зорі. Сучасність. 1978. С. $262-266$.

20. Соловій Ю. Розмова з Богданом Бойчуком. Про національне, понаднаціональне і релігійне у драмі «Голод». Сучасність. 1978. № 10. С. 81-92.

\section{REFERENCES}

1. Boichuk B. Navishcho pro tse hovoriu [Why am I talking about this]. Lviv: Piramida, 2017. 430 s. [in Ukrainian].

2. Boichuk B. Naperedodni "Holuboi hustyny" [On the eve of the "Holuba chustyna"]. Svoboda - Liberty. 21 bereznia 1968. Ch. 54. S. 4. [in Ukrainian].

3. Haidabura V. Letiuchyi korabel Lidii Krushelnytskoi [Flying ship of Lidiia Krushelnytska]. Studia Mystetskoho Slova v Niu-Yorku. K. : Fakt., 2006. 280 s. [in Ukrainian].

4. Dutchak V. H. Bandurne mystetstvo ukrainskoho zarubizhzhia XX-pochatku XXI stolittia: monohrafiia [Bandura art of Ukrainian Abroad in the 20th - early 21st centuries]; Prykarpat. nats. un-t im. Vasylia Stefanyka, Ivano-Frankiv. obl. orh. Nats. spilky kobzariv Ukrainy. Ivano-Frankivsk : Foliant, 2013. 488 s. [in Ukrainian].

5. Zaleska-Onyshkevych. Pered premieroiu "Holodu" [Before the premiere of "The Famine"]. Svoboda - Liberty. 16 kvitnia 1969. Ch. 69. S. 3. [in Ukrainian].

6. Karabovych T. Dosvid nadii ta samotnosti v literaturnomu dyskursi Bohdana Boichuka [The experience of hope and loneliness in Bohdan Boichuk's literary discourse]. Literaturnyi protses: metodologiia, imena, tendentsii. Filolohichni nauky. 2015. № 6. S. 122-127. URL: http://nbuv.gov.ua/UJRN/Litpro_2015_6_27. [in Ukrainian].

7. Karas H. V. Muzychna kultura ukrainskoi diaspory u svitovomu chasoprostori XX stolittia [Musical culture of the Ukrainian diaspora in the world time space of the twentieth century]. Ivano-Frankivsk: Tipovit., 2012. s. 1164. [in Ukrainian].

8. Konovalova M. M. Moderni eksperymenty u strukturi piesy B. Boichuka "Holod (1933)" [Modern experiments in the structure of B. Boichuk's play "The Famine (1933)"]. Visnyk Donetskoho natsionalnoho universytetu. Ser. B: Humanitarni nauky. 2015. № 1-2. S. 135-139. URL: http://nbuv.gov.ua/UJRN/vdnug_2015_1-2_25. [in Ukrainian].

9. Koniushko H. Trahediia narodu -drama liudstva. Pro Boichukovu dramu "Holod" $i$ ii postavu [The tragedy of the people is the drama of humanity. About Boichuk's drama "The Famine" and its posture]. Svoboda-Liberty. 30 kvitnia 1969. Ch. 79. S. 2. [in Ukrainian].

10. Kosarieva H. S. Metamystetstvo Bohdana Boichuka: teatralno-literaturni refleksii u zbirtsi statei "Navishcho ya pro tse hovoriu" [Bohdan Boichuk metafiction: theatrical and literary reflections in the collection of articles "Why am I talking about this"]. Naukovi pratsi: nauk. zhurn. / Chornom. nats. un-t im. Petra Mohyly; red. kol.: O. V. Pronkevych (holova) [ta in.]. Mykolaiv, 2019. T. 325. Vyp. 313. S. 55-60. [in Ukrainian].

11. Kukuruza N. Archiv N. V. Kukuruzy: interviu, audiozapysy, lystuvannia [Archive of N. V. Kukuruza: interviews, audio recordings, correspondence [Text; audio]. [in Ukrainian].

12. Kukuruza N. Vtilennia literaturnoi kompozytsii v ukrainskomu stsenichnomu mystetstvi: zhanrova i formotvorcha spetsyfika, istorychna dynamika [Implementation of Literary Composition in Ukrainian Performing Arts: Genre and FormBuilding Specificity, Historical Dynamics] (PhD Thesis), Kyiv: NAN Ukrainy, In-t mystetstvoznavstva, folklorystyky ta etnolohii im. M. T. Rylskoho, 2016. s. 20. [in Ukrainian].

13. Kukuruza N. Zhanr reviu v mystetstvi ukrainskoi diaspory: vytoky, kanon, imena, tematyka [Genre of revue in the art of the ukrainian diaspora: origins, canon, names, theme]. Ukrainska kultura: mynule, suchasne, shliakhy rozvytku. Rivne: RDHU, 2020. № 34. pp. 186-192. [in Ukrainian].

14. Kukuruza N. Tvorchist Lesi Ukrainky $v$ teatralnomu mystetstvi diaspory. Lesia Ukrainka $v$ diaspornomu literaturoznavstvi. Nimetsko-ukrainski zviazky [Lesya Ukrainka's creativity in the diaspora's theatrical art. Lesya Ukrainka in Diaspora Literary Studies. German-Ukrainian relations]. Proceedings of the Mizhnarodnoi naukovoi konferentsii v Miunkheni (Germany, Munich, April 3-7, 2019) (eds. D. Blokhyn, M. Moklytsia, T. Osadtsa), Miunkhen - Ternopil, 2019. pp. 38-147. [in Ukrainian].

15. Kukuruza N. Frankiana u mystetstvi khudozhnoho slova ukrainskoi diaspory 2 pol. XX-XXI storichchia [Frankiana in the art of artistic word of the Ukrainian diaspora in the second half of the 20-21'st centuries]. Ukrainska kultura: mynule, suchasne, shliakhy rozvytku. Rivne: RDHU, 2019. no. 32. pp. 19-25. [in Ukrainian].

16. Kukuruza N. Zhanrovo-formova spetsyfika vtilennia khydozhnoho slova v stsenichnomu mystetstvi ukrainskoi diaspory druhoi polovyny XX st. [Genre and form specificity of the implementation of spoken word in the stage art of the Ukrainian diaspora of the 2'nd half of 20'th century]. Dialoh mov-Dialoh kultur. Ukraina z hlobalnoi perspektyvy: materialy X Mizhnar. virtualnoi konf. ukrainoznavstva, Dortmund: Readbox GmbH, 2020. S. 590-597. [in Ukrainian].

17. Kukuruza N. Professional performing arts as an expression of national spiritual and cultural heritage of the Ukrainian diaspora. Art spiritual dimensions of Ukrainian diaspora: collective scientific monograph (Dutchak V., Karas' H., Dundiak I., Kozinchuk V., Kukuruza N., Novosiadla I., Fabryka-Protska O., Duda L., Fedorniak N., Obukh L., Kurbanova L., Sloniovska O.). Dallas, USA: Primedia eLaunch LLC, 2020. S. 107-145.

18. Poltava L. Za ukrainskyi repertuar dlia dytiachykh teatriv [For the Ukrainian repertoire for children's theaters]. Svoboda-Liberty. 2 kvitnia 1968. Ch. 62. S. 3. [in Ukrainian].

19. Solovii Y. Za novyi teatr, ale ne za "Novyi teatr" / Pro rechi bilshi nizh zori [For a new theater, but not for the "New Theater" / About things bigger than the stars]. Suchasnist. 1978. S. 262-266. [in Ukrainian].

20. Solovii Y. Rozmova z Bohdanom Boichukom. Pro natsionalne, ponadnatsionalne, i relihiine u drami "Holod" [Conversation with Bohdan Boichuk. About the national, supranational, and religious in the drama "The Famine"]. Suchasnist. 1978. № 10. S. 81-92. [in Ukrainian]. 